\title{
Early Neolithic jar burials in southeast Europe: a comparative approach
}

\author{
Krum Bacvarov \\ Institute of Archaeology and Museum, Bulgarian Academy of Sciences, Bulgaria \\ krum_bacvarov@sofianet.net
}

\begin{abstract}
A typical product of early farming symbolism, jar burial, appeared in the beginning of southeast European neolithization. Early jar burial development in south-east Europe displays two distinct chronological levels: an early Neolithic core area in the Struma and Vardar valleys and the western Rhodope, and later, late/final Neolithic and/or early Chalcolithic - depending on local terminology - manifestations 'scattered' in various places in the study area. It is the early chronological level of jar burial distribution that will be considered here in relation to the first expressions of these mortuary practices in Central Anatolia, in order to throw some light on the specifics of their origins and variability.
\end{abstract}

IZVLEČEK - Tipičen element zgodnjega simbolizma poljedelcev, pokop v posodi, se je pojavil na začetku procesa neolitizacije jugovzhodne Evrope. Zgodnji razvoj teh pokopov kaže dve kronološki stopnji: zgodnje neolitsko jedrno območje v dolinah rek Strume in Vardarja ter zahodnih Rodopih in mlajše, pozno/končno neolitske in/ali zgodnje bakrenodobne pokope - odvisno od terminologije, razpršene v regiji. V razpravi analiziramo najstarejše žarne grobove in jih v kontekstu izvora teh grobnih praks, primerjamo s pokopi v centralni Anatoliji.

KEY WORDS - jar burials; early chronological level; southeast Europe; Central Anatolia

\section{Introduction: grave pit interpretations}

The ordinary pit is reasonably conceived as the single archetype of burial structure. It is obviously the simplest, but sufficiently definite form of fulfillment of the idea of disposing of human remains through burial, which developed after the original covering of the deceased on the ground with grass, tree branches or hides, and later with soil and/or stones. Many of those who have explored southeast European Neolithic burials believe that the grave pit and hence the very burial of the dead has not been paid special attention; they illustrate their case with examples of refuse pit usage (Jovanović 1967.13; Garašanin1973.27; Brukner 1974). It was even proposed that intramural burials had not belonged to local community members, but to their defeated enemies, and that the dead of the respective Neolithic community were buried in extramural cemeteries.
In my opinion, the main reason for the wide circulation of this thesis in one form or another is the fact that most Neolithic burials lack grave goods and that the pits' backfill is the same soil of the cultural deposit, which contains various artifacts. Hence the seemingly reasonable conclusion that the dead were 'thrown away', but not buried.

Such an argument is unacceptable, especially if one considers the fact that, at least for the area of southeast Europe, it is based on the incorrect interpretation of grave pits as refuse pits. Certainly their backfill is often identical with that of refuse pits, and the difference between them is rather 'archaeologically elusive'. The presence of a great number of sherds and animal bones does not automatically transform pits into refuse pits, as is obvious, for in- 
stance, from two 'ritual pits' from Parţa I (Resch 1991; see also the analysis of the so-called structured deposition in Chapman 2000).

Moreover, there is the case with the re-use of already existing pits, for instance pits left from clay digging, as at Ajmana in the Danube Gorges (Stalio 1992.65-66), and of silos, as at Nea Nikomedeia in western Macedonia (Rodden 1962.286). On the other hand, there are unquestionable examples of 'rejection' or 'isolation' of the deceased, as at Vaxevo in the Struma Valley, where the situation unambiguously demonstrated that the dead body had been thrown into the pit (Cholakov 1991.231-232, Fig. 1; Chohadzhiev 2001.170-171, Fig. 10). Quite instructive in this respect is burial 285 at Çatalhöyük, which is the only one outside the buildings. Anthropological analysis shows pathological changes suggesting that the deceased young man probably suffered all his life from a serious disease which was the cause of his external deformities (Molleson et al. 1998).

And last, but not least, the 'refuse pits' interpretations always fail to consider burials beneath house floors, which are especially valuable as arguments against these allegations. These burials' position does not allow one to suppose that they belong to 'rejected' individuals; neither are they limited to infants and children only in order to be explained as 'sacrifices', although it is not very clear either why these so-called sacrifices should be related to children. In this sense, it is worth remembering that the burials in the Anatolian Neolithic and early Chalcolithic are most often not interpreted as belonging to marginal members of the local communities, and they generally correspond to the southeast European burials, both culturally and formally.

The grave pit was considered in the same semantic context as the contracted position of the dead body. If the symbolic meaning of the body position is generally assumed as embryonic, it is completely reasonable to view the pit as the womb of the female divinity, even though this 'Mother-Goddessist' interpretation would probably be considered by many as outdated. The later megalithic tombs in northern Europe had similar significance; their entrance was viewed as a divine vagina, and the bringing of the dead body into the tomb imitated the act of impregnation (Gräslund 1994.22-24). Of course, burial structures of a semantically similar plan existed as early as the Starčevo period at Zlatara in Srem and at Vinča-Belo Brdo (Vasić 1936.9-17; Leković 1985. 159-161), and are a logical development from or- dinary pits. It is clear that, as a whole, the mortuary rituals reproduced the mythological act of creation, and the burial features played a fundamental role in them.

\section{Jar burials: early types and distribution}

An additional argument here is the group of graves in southeast Europe where the human remains were buried in clay pots. This practice was common in the Levant, both in earlier and contemporary contexts. The clay pot itself was also considered as a womb, but this symbolic aspect had been secondarily stressed in burial contexts, as is the case with the later Alishar Hüyük, where two of the urns were modelled with conical 'breasts' (Schmidt 1932.72). In its symbolic aspect of container, the womb of the female divinity or the mother goddess, if one should use the convenient term, the pot - without respect to the material - played a significant role in many rituals, all the more so in historical times. One specific feature of the burial in clay pots in the Neolithic, which differentiates it from the evolution of this practice in later periods, is the re-use of vessels, which originally had a different function and had not been made especially for burial. The original purpose - both real and symbolic - of clay pots from Neolithic sites remains unknown, but the tradition of burying in silos can be traced back to the Levant. It is worth considering the burials at Ajmana and Nea Nikomedeia once again and especially the original purpose of the grave pits: the former was a pit left from clay digging, and the latter was an old silo. Certainly one should not belittle the expedient aspects of re-using pits but it is evident that there is a semantic similarity to the clay pot on the one hand, and to grain, on the other. The burial in a vessel/pit - which is a container/womb - obviously reproduced the mythological act of creation; it confirms again the symbolic relationship between grave/death/burial and grain/fertility/rebirth (Bacvarov 2003.129133). In this sense, on a practical level, these clay pots were originally used as food containers, as cooking pots or for other purposes, and were later re-used in burials as death-containing vessels; on a symbolic level they were originally used as containers of culturally transformed or transforming matter, or matter prepared for transformation in the future, and were later re-used in burials as 'birth-giving' vessels. All these were different aspects of the same concept in the religio-mythological beliefs of early farmers.

Nevertheless, burials in clay pots do not constitute a homogenous group, but can be separated into 
three different types, each with specific features. I will consider them here with respect to their origins and territorial distribution.

A total of four cases of individual formal inhumation in a clay pot - or typical jar burials - have been found in southeast Europe: two at Kovačevo in the Struma Valley, one at Rakitovo in the Rhodope and one at Anza in the Vardar Valley (Lichardus-Itten et al. 2002.116, 127, Pl. 9, 1-2; 10, 1; Raduncheva et al. 2002.35, 150-151, obr. 24/2, 12; 81/3; Gimbutas 1976.397, Fig. 242, Pl. 47). All four complexes date back to the early Neolithic: the first three burials belong to the Karanovo I culture, and the fourth belongs to the Kremenik-Anzabegovo culture. The burial from Rakitovo was found near the western wall of a house, beneath the floor, and the other three graves were discovered between houses. All vessels were pots, one of which - that from Kovačevo - had a clay lid. The globular pithos from Anza had four broken handles and a broken bottom, most probably intentionally. Grave goods were found only in the Rakitovo burial: a flint tool and lumps of red ochre. The skeletal remains belong to newborn or stillborn infants buried in a contracted position. Only one of the Kovačevo skeletons was explored in situ by an anthropologist and in this case the position was found to be contracted on the right side, with the head aligned to the north. It is worth mentioning that a total of seven infant or children burials were excavated at the same site, and only two of them, belonging to stillborn/newborn babies, were interred in clay pots, whereas the rest belong to children buried in ordinary pits. In one case the dead child was wrapped in a thick cover, probably a mat or possibly a sack.

As far as I am concerned, this practice had no parallels in the neighbouring areas, neither culturally nor chronologically. The closest analogies are three jar burials from Kösk Höyük and Pinarbasi-Bor in Central Anatolia, which were also found beneath house floors like the Rakitovo grave, and belong to the Anatolian late Neolithic/early Chalcolithic (Yakar 1991. 192). On the other hand, however, this tradition probably originated in the Levant, where it had already become quite common and was related, for instance, to the archaic Hassuna culture and the Tell Sotto culture. Six jar burials at the eponymous site at Tell Sotto and one burial at Tell Hazna II are especially instructive (Bader 1989.132-135, Tab. 47/1-2; Munchaev et al. 1993.27-34). The strong influence of Levantine traditions on the life and culture at Kösk Höyük, especially on mortuary practices, manifested itself in the local variant of the 'skull cult' which was observed at that Anatolian site. The earliest 'decorated' skulls of this kind were found at Jericho. The skull from Kösk Höyük, however, was found in Layer III, which resembles the late Neolithic at Çatalhöyük, whereas the skulls from Jericho are of a much earlier date.

The second type comprises only one Neolithic grave related to a secondary collective burial. It was discovered in Layer III at Tell Azmak in Thrace and belongs to the early Neolithic Karanovo I culture. The clay pot contained several skulls (the excavator does not give the exact number) as well as separate bones (Georgiev 1966.9-10). This find remains unique and could be related only to the secondary collective burials in ordinary pits, from Layer II and IV of Tell Karanovo, for instance (Bacvarov 2000).

This is not the case with the last type, known from as many as six sites in southeast Europe and related to cremation burial. A large clay pot containing the burnt bones of a child was found close to the oven in a house from the early Neolithic layer at Tell Azmak. The pot was very probably buried beneath the house floor, but this is not explicitly stated in the only source available: the ground plan of the house published in 1972 (Georgiev 1972.17, Abb. 4). This burial is not unique in the southeast European early Neolithic, although it is the only one found in Thrace. Cremation burials in clay pots were found in the late Starčevo layer at Vinča-Belo Brdo and at the Körös site of Gorza in the Tisza Valley (Vasic 1936.182; Gazdapusztai 1957). The burials from Vinča and Gorza formally correspond to the Azmak complex; the calcined bones were interred in clay pots.

Cremation was known as a ritual practice as early as the Upper Palaeolithic, but the bones were often only burnt superficially (Binant 1991.145-140). Such burials were also found at Epipaleolithic sites, although rather occasionally. However, it is possible that the separate burnt human bones were not recognized and collected together with the animal bones, as is the case with the Franchti cave, where skeletal remains of about thirty individuals were recovered after careful sieving of the soil and analysis of the animal bones (Cullen 1995.274). More numerous examples of cremation burials in pots come from the late Neolithic layers at Souphli Magoula and Plateia Magoula Zarkou in eastern Thessaly (Gallis 1975; 1996a; 1996b). At Souphli, besides the charred skeletal remains buried in round pits with grave goods and belonging to the early Neolithic Protosesklo culture, 
seven pots containing charred bones were found to the south of the Magoula, belonging to the TzangliLarissa phase of the Dimini culture. The cemetery of Plateia was excavated at less than five hundred meters from the site; it contained more than seventy cremation burials in clay pots covered with other vessels, in one case a zoomorph. The grave pits were surrounded with stones, or in some cases the bottoms of the pits were covered with a layer of pebbles. Smaller vessels were buried as grave goods.

There are many different interpretations of the Neolithic cremation burials, ranging from purification to ways of releasing the spirit. Ina Wunn assumes that the burials from Souphli and Plateia are clear indicators of a belief in the existence of a soul which detaches from its earthly shell through cremation, thus facilitating its transformation into another existential form (Wunn 2001.134-137). I cannot agree with the idea that these practices were the result of the elaboration of concepts of an afterworld, because they appeared too early. It is rather that the cremation burial was considered in the same religio-mythological context as inhumation in a contracted position, but in an aspect more closely related to fire. This conclusion is supported by the fact that in most cases the cremated human remains were interred in clay pots, whose symbolic meaning has already been considered here. The position of the Azmak burial near the oven should be viewed in the same light.

Certain additional hints to the interpretation of the symbolism of cremation burials in clay pots are found in the fact that the complexes at Tell Azmak and Gorza are earlier, whereas the graves at Vinča, Souphli and Plateia are of later date. Moreover, the Azmak burial - and probably the burial from Gorza was of a child, which perhaps relates it more closely to formal individual inhumations than to the typical late Neolithic cremation burials; it should be noted also that it was found beneath a house floor.

\section{Instead of a conclusion: Late/Final Neolithic and Chalcolithic development}

Jar burial continued to be practiced in the late/final Neolithic and the Chalcolithic of southeast Europe. Six more burials were found beneath house floors or outside houses. A new element here was the use of bowls to contain or cover the infants' bodies, while in the early Neolithic cases, only pots had been used. Such a burial of a neonate, covered by a deep, darkburnished bowl with channelling was found at Tell Ezero in Upper Thrace and date back to the late Neo- lithic Karanovo III period (Georgiev et al. 1979.40). They are similar to the final Neolithic cases at the tells at Mandalo in northern Greece and Lerna in Argolis, where two more burials were uncovered under house floors, in an open undecorated bowl and a patterned beaker, respectively (Caskey 1957.159). However, the old tradition of burial in pots also survived in the same areas it had been practiced before, as is suggested by the infant burials at Polgár, site 7 (Alföld Linear Pottery Culture) in the Great Hungarian Plain, and in the Kouveleiki cave in Laconia, Greece (Papathanassopoulos 1996), as well as the burials at Rachmani in Thessaly (Wace and Thompson 1912).

Nine more jar burials were found in the cemeteries at Mórágy-Túzkódomb (southern Transdanubia), Durankulak (Dobruja), and Kephala on the Cycladic island of Keos, which belong to the late Neolithic Lengyel culture, Hamangia III and the final Neolithic, respectively (Zalai-Gaál 2002; Todorova 2002; Fowler 2004).

An early draft of this paper was presented in 2003 at the international symposium in Stara Zagora, Bulgaria, and was later published in its proceedings. I am grateful to Dr. Mihael Budja, who kindly invited me to take part in the $12^{\text {th }}$ Neolithic Seminar and to present an updated version of this research project. I should also acknowledge here Professor Pál Raczky, who kindly shared the information about the unpublished jar burial from Polgár with me. 


\section{REFERENCES}

BACVAROV K. 2000. The Karanovo Neolithic Mortuary Practices in their Balkan and Anatolian Context. In S. Hiller and V. Nikolov (Hrsg.), Karanovo, 3. Beiträge zum Neolithikum in Südosteuropa. Wien, Phoibos: 137-140.

2003. Neolitni pogrebalni obredi: intramuralni grobove ot balgarskite zemi $v$ konteksta na Yugoiztochna Evropa $i$ Anatolia. Bard. Sofia.

BADER N. 0. 1989. Drevneyshie zemledeltsy Severnoy Mesopotamii. Moskva.

BINANT P. 1991. La préhistoire de la mort: les premières sépultures en Europe. Paris.

BRUKNER B. 1974 Rani neolit. In B. Brukner, B. Jovanović and N. Tasić (eds.), Praistorija Vojvodine. Novi Sad: $29-68$.

CASKEY J. L. 1957. Excavations at Lerna: 1956. Hesperia 26: $142-162$

CHAPMAN J. C. 2000 Pit-digging and Structured Deposition in the Neolithic and Copper Age. Proceedings of the Prehistoric Society 66: 1-27.

CHOHADZHIEV S. 2001. Vaksevo. Praistoricheski selishta. Faber. Veliko Tarnovo.

CHOLAKOV S. 1991. Antropologichno prouchvane na kostni ostanki ot rannoneolitnoto selishte pri s. Vaksevo, Kyustendilsko. Izvestiya na Istoricheskiya muzey - Kyustendil 3: 231-244.

CULLEN T. 1995. Mesolithic Mortuary Ritual at Franchthi Cave, Greece. Antiquity 69: 270-289.

FOWLER K. D. 2004. Neolithic Mortuary Practices in Greece. British Archaeological Reports S1314, Archaeopress, Oxford.

GALLIS K. 1975. Kauseis nekron apo tin Arhaisteran Neolithikin epohin tin Thessalian. Arhaiologika analekta ex Athinon 8(2): 241-258.

1996a. Burial Customs. In G. Papathanassopoulos (ed.), Neolithic Culture in Greece: 171-174. Athens.

1996b. Ausgrabungen der neolithischen Siedlungen und Fiedhöfe von Platia Magoula Zarkou, Souphli-Magula und Makrychori 2 in Thessalien. In E. Alram-Stern (ed.), Die Ägäische Frühzeit: 521-562. Wien.

GARAŠANIN M. 1973. Praistorija na tlu SR Srbije. Beograd. GAZDAPUSZTAI G. 1957. A Körös-kultúra lakótelepe Hódmezôvásárhely-Gorzsán. Archaeologiai Értesító 85: 3-13.
GEORGIEV G. I. 1966. Mnogosloynoe poselenie Azmashka mogila bliz Staroy Zagory (Bolgaria). Kratkie soobshteniya Instituta arheologii 106: 3-10.

1972. Das Neolithikum und Chalkolithikum in der Thrakischen Tiefebene (Südbulgarien). Thracia, 1 (Probleme des heutigen Forschungsstandes): 5-27.

GEORGIEV G. I., MERPERT N., KATINCHAROV R. and DIMITROV D. (eds.) 1979. Ezero. Rannobronzovoto selishte. Balgarska akademia na naukite. Sofia.

GIMBUTAS M. (ed.) 1976. Neolithic Macedonia as Reflected by Excavations at Anza, Southern Yugoslavia. (Monumenta Archaeologica, 1). UCLA Institute of Archaeology. Los Angeles.

GRÄSLUND B. 1994. Prehistoric Soul Beliefs in Northern Europe. Proceedings of the Prehistoric Society 60: 1526.

JOVANOVIĆ B. 1967. Znachenje nekih kultnih elemenata starchevachke grupe. Starinar 18: 11-22.

LEKOVIĆ V. 1985. The Starčevo Mortuary Practices - New Perspectives. Godišnjak Centra za Balkanološka ispitivanja 23: 157-172.

LICHARDUS-ITTEN M., DEMOULE J.-P., PERNIČEVA L., GREBSKA-KULOVA M. and KULOV I. 2002. The site of Kovačevo and the Beginnings of the Neolithic Period in Southwestern Bulgaria. The French-Bulgarian excavations 1986-2000. In M. Lichardus-Itten, J. Lichardus, und V. Nikolov (Hrsg.), Beiträge zu jungsteinzeitlichen Forschungen in Bulgarien. (Saarbrücker Beiträgen zum Altertumskunde, 74). Habelt, Bonn: 99-158.

MOLLESON T., ANDREWS P., BOZ B., DEREVENSKI J. and PEARSON J. 1998. Human Remains up to 1998. In Çatalhöyük 1998 Archive Report [http://catal.arch.cam.ac.uk/ catal/Archive_rep98/molleson98.html].

MUNCHAEV R. M., MERPERT N. Y., BADER N. O. and AMIROV S. N. 1993. Tell Hazna II - rannezemledelcheskoe poselenie v Severo-vostochnoy Sirii. Rossiiskaya arheologia 4: 25-42.

PAPATHANASSOPOULOS G. 1996. Burial Customs at Diros. In G. Papathanassopoulos (ed.), Neolithic Culture in Greece. Athens: 175-177.

RADUNCHEVA A., MATSANOVA V., GATSOV I., KOVACHEV G., GEORGIEV G., CHAKALOVA E. and BOZHILOVA E. 2002. Neolitno selishte do grad Rakitovo. (Razkopki i prouchvaniya 29) Gal-Iko. Sofia. 
RESCH F. 1991 Typologische Studien kultischer Gesichtsdeckel aus der jungsteinzeitlicher Siedlung von Parţa I. Banatica 11: 185-192.

RODDEN R. 1962. Excavations at the Early Neolithic Site at Nea Nikomedeia, Greek Macedonia (1961 season). Proceedings of the Prehistoric Society 28: 267-288.

SCHMIDT E. F. 1932. The Alishar Hüyük, I. Seasons of 1928 and 1929. Oriental Institute Publications: 19. University of Chicago.

STALIO B. 1992 Grupno sahranjivanje na Ajmani - Mala Vrbica. Zbornik Narodnog muzeja 14(1): 65-78.

TODOROVA H. (ed.) 2002. Die prähistorischen Gräberfelder (Durankulak II). Deutsches Archäologisches Institut. Sofia.
VASIĆ M. 1936. Preistoriska Vinča II. Beograd.

WACE A. J. B. and THOMPSON M. S. 1912. Prehistoric Thessaly. Cambridge.

WUNN I. 2001. Götter, Mütter, Ahnenkult. Religionsentwiklung in der Jungsteinzeit. Oldenburg.

YAKAR Y. 1991. Prehistoric Anatolia. The Neolithic Transformation and the Early Chalcolithic Period. Monograph Series of the Institute of Archaeology. Tel Aviv University. Tel Aviv.

ZALAI-GAÁL I. 2002. Die Neolithische Gräbergruppe-B1 von Mórágy-Túzkódomb, I. Die archäologische Funde und Befunde. Wosinsky Mór Múzeum. Szekszárd-Saarbrücken. 